\title{
FORMS OF NEWLY RETAINED PHOSPHORUS IN MINERAL SOILS
}

\author{
Armi KaILA \\ University of Helsinki, Department of Agricultural Chemistry
}

Received January 11, 1964

In most soils a large part of the added water-soluble phosphate will be rapidly removed from solution by soil constituents. The mechanism involved may be adsorbtion or chemical precipitation, and the products formed are likely to represent a large variety of compounds with aluminium, iron, or calcium, and their oxides and hydroxides. Usually, more than 80 per cent of the added soluble phosphate is fixed as aluminium and iron compounds, and only in soils with a high calcium carbonate content retention as calcium compounds may be marked $(8,12,14)$.

In the present paper an attempt is made to study the distribution of applied water-soluble phosphate in the various fractions of inorganic phosphorus in Finnish mineral soils, over a relatively short period of contact. The fractionation procedure by CHANG and JAckson (3) is employed. The possible connection is tried to be found between the net increase in the various phosphorus fractions and soil properties such as the contents of active aluminium and iron, $\mathrm{pH}$, the content of organic carbon, the phosphate fixing capacity, and the degree of phosphorus saturation.

Methods

Soil $\mathrm{pH}$ was measured in a 1 to 2.5 suspension in $0.01 \mathrm{M} \mathrm{CaCl}_{2}$ by the glass electrode. The content of organic carbon was determined by the Walkley method using the iodometric titration.

Aluminium and iron were extracted by Tamm's acid ammonium oxalate solution in the ratio of soil to solution of 1 to 20 , the period of extraction was two hours. Aluminium was determined by the Aluminon method, and iron by the sulfosalicylic acid procedure, after the organic matter in the extract was destructed by ignition.

The indicator of the phosphate sorption capacity, k, was estimated by a somewhat modified method of TERÄsvuORI (6) which is based on the Freundlich adsoption isotherm. The degree of saturation $\mathrm{y}_{o} / \mathbf{k}$, is, accordning to TERÃsvUORI, the ratio between the sexchangeables $\mathrm{P}$, or P extracted by alkali, and the indicator of the sorption capacity.

The soil samples were treated with water-soluble phosphate in the following way: $1 \mathrm{~g}$ of air-dried and ground soil was weighed in a centrifuge tube, and $50 \mathrm{ml}$ of $\mathrm{KH}_{2} \mathrm{PO}_{4}$ solution containing $5 \mathrm{mg} \mathrm{P} / 1$ was added. The tube was shaken by machine for 4 hours, let stand over night, and shaken for 2 hours 
before centrifuging. The supernatant solution was decanted, and its content of $\mathrm{P}$ determined. The moist soil in the centrifuge tube was let stand for 3 days at room temperature, washed with saturated NaClsolution, and successively extracted with alkaline $0.5 \mathrm{~N} \mathrm{NH}_{4} \mathrm{~F}, 0.1 \mathrm{~N} \mathrm{NaOH}$, and $0.5 \mathrm{~N} \mathrm{H}_{2} \mathrm{SO}_{4}$ according to the procedure by CHANG and JACKSON (3). Untreated samples were fractionated in the same way, and the difference between the phosphorus contents of the treated and untreated samples was taken to represent the increase due to the added $\mathrm{P}$.

\section{Soil samples}

180 samples of mineral soils were collected from various parts of the country both from the plough layer, or the corresponding layer in the virgin soils, and from the deeper layers between the depths of $20 \mathrm{~cm}$ and $70 \mathrm{~cm}$. Since only 21 samples were from the virgin lands, they were not treated separately.

According to the results of the mechanical analysis, the samples were divided to the groups of sand and fine sand soils with less than 30 per cent clay and more than 50 per cent fine sand, loam and silt soils with less than 30 per cent clay and less than 50 per cent fine sand, and the group of clay soils with more than 30 per cent clay. The number of samples in the various groups and the means of the $\mathrm{pH}$ values, the contents of organic carbon, and oxalate soluble aluminium and iron are listed in Table 1.

The low acidity of some glacial clay soils of the deeper layers increases the mean $\mathrm{pH}$ of the groups of subsoil samples and clay soil samples. In the other groups the mean $\mathrm{pH}$ value is rather low.

Table 1. Soil samples

\begin{tabular}{|c|c|c|c|c|c|}
\hline & \multirow{2}{*}{\multicolumn{2}{|c|}{$\begin{array}{c}\text { Number } \\
\text { of } \\
\text { samples }\end{array}$}} & \multirow{2}{*}{$\begin{array}{l}\text { Org. C } \\
\%^{*}\end{array}$} & \multicolumn{2}{|c|}{ Oxalate soluble } \\
\hline & & & & $\begin{array}{c}\mathrm{Al}^{*} \\
\mathrm{mmol} / \mathrm{kg}\end{array}$ & $\begin{array}{c}\mathrm{Fe}^{*} \\
\mathrm{mmol} / \mathrm{kg}\end{array}$ \\
\hline \multicolumn{6}{|l|}{ Topsoil } \\
\hline Sand and fine sand & 45 & $5.2 \pm 0.2$ & $3.7 \pm 0.7$ & $95 \pm 15$ & $67 \pm 9$ \\
\hline Loam and silt & 38 & $5.2 \pm 0.2$ & $3.8 \pm 0.6$ & $101 \pm 17$ & $81 \pm 8$ \\
\hline Clay & 47 & $5.2 \pm 0.2$ & $3.8 \pm 0.4$ & $123 \pm 15$ & $121 \pm 18$ \\
\hline All & 130 & $5.2 \pm 0.1$ & $3.7 \pm 0.4$ & $107 \pm 9$ & $90 \pm 8$ \\
\hline \multicolumn{6}{|l|}{ Subsoil } \\
\hline Sand and fine sand & 17 & $5.2 \pm 0.2$ & $0.8 \pm 0.3$ & $138 \pm 52$ & $67 \pm 20$ \\
\hline Loam and silt & 10 & $5.3 \pm 0.4$ & $0.7 \pm 0.3$ & $80 \pm 42$ & $70 \pm 22$ \\
\hline Clay & 23 & $5.6 \pm 0.3$ & $0.4 \pm 0.1$ & $78 \pm 8$ & $56 \pm 8$ \\
\hline All & 50 & $5.6 \pm 0.2$ & $0.6 \pm 0.1$ & $99 \pm 20$ & $63 \pm 8$ \\
\hline \multicolumn{6}{|l|}{ All } \\
\hline Sand and fine sand & 62 & $5.2 \pm 0.2$ & - & $107 \pm 18$ & $67 \pm 24$ \\
\hline Loam and silt & 48 & $5.2 \pm 0.2$ & - & $96 \pm 15$ & $78 \pm 7$ \\
\hline Clay & 70 & $5.5 \pm 0.2$ & - & $108 \pm 11$ & $99 \pm 14$ \\
\hline
\end{tabular}

* Means with the confidence limits at the 95 per cent level 
In the topsoil samples, the content of oxalate soluble aluminium and iron tend to increase from sand and fine sand to clay soils, but in the subsoil samples the sand and fine sand group has a higher mean content of aluminium than the clay soils have.

The phosphorus condition of the soil groups is characterized by the data in Table 2. In the topsoils, the phosphate sorption capacity tends to be highest in the clay soils and lowest in the loam and silt soils. In the subsoil samples, some of the sand and fine sand soils have a markedly high capacity. The average degree of saturation with phosphate is almost equal in all the groups of topsoil samples, on one hand, and in all the groups of subsoil samples, on the other hand, with a statistically insignificant tendency for the highest value in the loam and silt soils.

In the sand and fine sand soils the ammonium fluoride soluble inorganic phosphorus ("Al-P» in Table 2) tends to be higher than in the other soils, and not markedly lower than the alkali-soluble phosphorus $(n \mathrm{Fe}-\mathrm{P} n)$. This fraction is highest in the clay soils from the surface layer. The acid-soluble phosphorus ("Ca-P») tends to be lower

Table 2. Indicator of phosphate sorption capacity, k, degree of saturation, $y_{0} / \mathbf{k}$, and fractions of inorganic $\mathrm{P}(\mathrm{ppm})$ in the soil groups. (Mean values with the confidence limits at the 95 per cent level.)

\begin{tabular}{|c|c|c|c|c|c|}
\hline & $\mathbf{k}$ & $\mathrm{y}_{0} / \mathrm{k}$ & $\mathrm{A} 1-\mathrm{P}$ & Fe-P & ${ }^{\prime} \mathrm{Ca}-\mathrm{P}$ \\
\hline \multicolumn{6}{|l|}{ Topsoil } \\
\hline Sand and fine sand & $249 \pm 38$ & $0.76 \pm 0.13$ & $98 \pm 29$ & $139 \pm 34$ & $150 \pm 30$ \\
\hline Loam and silt & $199 \pm 27$ & $0.78 \pm 0.11$ & $62 \pm 21$ & $142 \pm 25$ & $188 \pm 40$ \\
\hline Clay & $337 \pm 55$ & $0.74 \pm 0.06$ & $72 \pm 15$ & $218 \pm 30$ & $194 \pm 27$ \\
\hline All & $267 \pm 26$ & $0.76 \pm 0.06$ & $78 \pm 13$ & $169 \pm 18$ & $177 \pm 18$ \\
\hline \multicolumn{6}{|l|}{ Subsoil } \\
\hline Sand and fine sand & $319 \pm 134$ & $0.43 \pm 0.10$ & $58 \pm 20$ & $76 \pm 25$ & $136 \pm 65$ \\
\hline Loam and silt & $176 \pm 116$ & $0.50 \pm 0.15$ & $22 \pm 16$ & $102 \pm 84$ & $325 \pm 143$ \\
\hline Clay & $223 \pm 34$ & $0.35 \pm 0.05$ & $15 \pm 3$ & $98 \pm 15$ & $315 \pm 52$ \\
\hline All & $246 \pm 52$ & $0.41 \pm 0.05$ & $31 \pm 9$ & $88 \pm 18$ & $256 \pm 47$ \\
\hline \multicolumn{6}{|l|}{$A \|$} \\
\hline Sand and fine sand & $268 \pm 45$ & $0.67 \pm 0.10$ & $85 \pm 22$ & $119 \pm 26$ & $146 \pm 27$ \\
\hline Loam and silt & $194 \pm 30$ & $0.72 \pm 0.10$ & $54 \pm 17$ & $134 \pm 25$ & $216 \pm 43$ \\
\hline Clay & $300 \pm 40$ & $0.61 \pm 0.06$ & $53 \pm 12$ & $175 \pm 25$ & $234 \pm 28$ \\
\hline
\end{tabular}

in the sand and fine sand soils than in the other groups. The typical differences between the forms of phosphorus in the topsoils and subsoils is evident: the topsoils contain more fluoride-soluble and alkali-soluble phosphorus than the subsoils, but less acid-soluble phosphorus. 


\section{Fractions of sorbed phosphate}

The amount of phosphorus retained by the soil samples during the treatment with $\mathrm{KH}_{2} \mathrm{PO}_{4}$-solution was calculated on the basis of the phosphorus concentration in the solution removed by centrifuging (Table 3.). In the group of the topsoil samples this amount was highest in the clay soils, but in the subsoil samples a fairly high retention occurred also in the group of the sand and fine sand soils. On the average, about one half of the $250 \mathrm{mg}$ of phosphorus added per kilogram of soil was retained during the period of contact of 24 hours. Very little phosphorus was removed by the washing with saturated $\mathrm{NaCl}$ which means that after the further three days of contact only a small part of the added phosphate remained in easily soluble forms. Only in the groups of the clay soils, the total amount of phosphorus recovered by the fractionation is somewhat lower than the amount calculated on the basis of the phosphate concentration in the solution removed.

Table 3. Phosphorus sorbed by the samples

(Means with the confidence limits at the 95 per cent level)

\begin{tabular}{|c|c|c|c|c|}
\hline & \multirow{2}{*}{$\begin{array}{c}\text { Sorbed P } \\
\% \\
\text { of added P }\end{array}$} & \multicolumn{3}{|c|}{$\begin{array}{l}\text { Sorbed P ppm } \\
\text { extracted by }\end{array}$} \\
\hline & & $\mathrm{NH}_{4}-\mathrm{F}$ & $\mathrm{NaOH}$ & $\mathrm{H}_{2} \mathrm{SO}_{4}$ \\
\hline \multicolumn{5}{|l|}{ Topsoil } \\
\hline Sand and fine sand & $41 \pm 6$ & $62 \pm 11$ & $40 \pm 10$ & $3 \pm 3$ \\
\hline Loam and silt & $44 \pm 5$ & $64 \pm 12$ & $38 \pm 6$ & $5 \pm 3$ \\
\hline Clay & $56 \pm 5$ & $71 \pm 9$ & $61 \pm 11$ & $3 \pm 3$ \\
\hline All & $47 \pm 3$ & $67 \pm 6$ & $47 \pm 6$ & $4 \pm 2$ \\
\hline \multicolumn{5}{|l|}{ Subsoil } \\
\hline Sand and fine sand & $55 \pm 14$ & $88 \pm 24$ & $43 \pm 13$ & $5 \pm 5$ \\
\hline Loam and silt & $43 \pm 16$ & $58 \pm 23$ & $48 \pm 22$ & $3 \pm 7$ \\
\hline Clay & $57 \pm 6$ & $61 \pm 5$ & $57 \pm 8$ & $5 \pm 5$ \\
\hline All & $54 \pm 14$ & $70 \pm 10$ & $51 \pm 7$ & $5 \pm 3$ \\
\hline \multicolumn{5}{|l|}{$A l l$} \\
\hline Sand and fine sand & $45 \pm 6$ & $69 \pm 10$ & $41 \pm 8$ & $4 \pm 2$ \\
\hline Loam and silt & $44 \pm 5$ & $63 \pm 10$ & $40 \pm 6$ & $5 \pm 3$ \\
\hline Clay & $57 \pm 4$ & $68 \pm 6$ & $60 \pm 8$ & $4 \pm 2$ \\
\hline
\end{tabular}

In all the soil groups the largest part of sorbed phosphorus is extracted by ammonium fluoride, but in the groups of clay soils and in the subsoil samples of loam and silt soils the alkali-soluble fraction is not statistically significantly lower than the fluoride soluble fraction. The amount of phosphorus left in the acid-soluble fraction is low. In about two thirds of the samples no increase in the phosphorus content of this fraction could be detected as a result of the treatment with the phosphate solution. 
No statistically significant difference occurs between the various kinds of soils, or between the samples of topsoil and subsoil, in the amount of sorbed phosphorus extracted by fluoride. The amount of sorbed phosphorus in the alkali extract is highest in the clay soils, although their superiority in this respect is not statistically significant in the subsoil samples. Thus it seems that the various soils accumulate about the same amounts of applied phosphorus in the fraction supposed to be bound by aluminium, and the more effective sorption of the clay soils is due to a larger accumulation of iron bound phosphorus.

In all the samples, both topsoil and subsoil, on the average, about 56 per cent of the sorbed phosphorus is in the fluoride soluble fraction and about 40 per cent in the alkali-soluble forms. In the various soil groups this percentile distribution is the following:

topsoil samples

sand and fine sand

loam and silt

clay

subsoil samples

sand and fine sand

loam and silt

clay fluoride-soluble $\mathrm{P}$ alkali-soluble $\mathrm{P}$

$\begin{array}{ll}59 \% & 38 \% \\ 60 \% & 36 \% \\ 53 \% & 45 \% \\ & \\ 65 \% & 32 \% \\ 53 \% & 44 \% \\ 50 \% & 46 \%\end{array}$

Also these figures show the relative great importance of iron in the retention of phosphorus by clay soils as compared especially with the retention by the sand and fine sand soils.

Table 4. Ratio between acid oxalate soluble aluminium and iron and between the amounts of phosphorus extracted by $\mathrm{NH}_{4} \mathrm{~F}$ and $\mathrm{NaOH}$

(Means with the confidence limits at the 95 per cent level)

\begin{tabular}{|c|c|c|c|c|}
\hline & $\mathrm{Al} / \mathrm{Fe}$ & initial & $\begin{array}{l}\mathrm{Al}-\mathrm{P} / / \mathrm{Fe}-\mathrm{P} \\
\text { sorbed }\end{array}$ & total \\
\hline \multicolumn{5}{|l|}{ Topsoil } \\
\hline Sand and fine sand & $1.5 \pm 0.2$ & $0.7 \pm 0.1$ & $2.5 \pm 0.7$ & $1.1 \pm 0.2$ \\
\hline Loam and silt & $1.2 \pm 0.1$ & $0.4 \pm 0.06$ & $1.8 \pm 0.3$ & $0.8 \pm 0.1$ \\
\hline Clay & $1.1 \pm 0.1$ & $0.3 \pm 0.08$ & $1.5 \pm 0.4$ & $0.6 \pm 0.1$ \\
\hline All & $1.3 \pm 0.1$ & $0.5 \pm 0.06$ & $1.9 \pm 0.3$ & $0.8 \pm 0.1$ \\
\hline \multicolumn{5}{|l|}{ Subsoil } \\
\hline Sand and fine sand & $2.0 \pm 0.6$ & $0.7 \pm 0.2$ & $2.1 \pm 0.8$ & $1.2 \pm 0.3$ \\
\hline Loam and silt & $1.1 \pm 0.4$ & $0.2 \pm 0.16$ & $1.4 \pm 0.3$ & $0.7 \pm 0.2$ \\
\hline Clay & $1.5 \pm 0.2$ & $0.2 \pm 0.02$ & $1.2 \pm 0.2$ & $0.6 \pm 0.2$ \\
\hline All & $1.6 \pm 0.2$ & $0.4 \pm 0.1$ & $1.5 \pm 0.3$ & $0.8 \pm 0.1$ \\
\hline \multicolumn{5}{|l|}{$A l l$} \\
\hline Sand and fine sand & $1.7 \pm 0.2$ & $0.7 \pm 0.1$ & $2.5 \pm 0.5$ & $1.2 \pm 0.2$ \\
\hline Loam and silt & $1.2 \pm 0.1$ & $0.4 \pm 0.06$ & $1.7 \pm 0.2$ & $0.7 \pm 0.1$ \\
\hline Clay & $1.2 \pm 0.1$ & $0.3 \pm 0.06$ & $1.4 \pm 0.3$ & $0.6 \pm 0.1$ \\
\hline
\end{tabular}


It is of interest to study in more detail the distribution of the added phosphorus between the fractions which are supposed to be bound by aluminium or iron. The ratios between these fractions in the original samples and the samples treated with phosphorus were calculated and are listed in Table 4, which also contains the ratios between the aluminium and iron (as mols) extracted by acid ammonium oxalate.

In accordance with some previous results (7), the ratio of fluoride soluble phosphorus to alkali soluble phosphorus is in the untreated soils rather low, and in the sand and fine sand soils significantly higher than in the soils of the finer texture. The same order between the soil groups may be found also in respect to the ratios of these fractions in the samples treated with phosphorus and the ratios of the net increase in these fractions due to the treatment. The ratio of the sorbed "Al-P» to the sorbed $" \mathrm{Fe}-\mathrm{P} "$ is in all soil groups markedly higher than the corresponding ratio in the untreated samples, thus indicating that the distribution of the applied phosphorus in these fractions is essentially different from the distribution of the inorganic phosphorus which has been in contact with the soil for a longer period. The ratio of the mols of the oxalate soluble aluminium to iron is highest in the sand and fine sand soils which offers an explanation for the corresponding order in the ratios of aluminium bound and iron bound phosphorus in the soil groups.

\section{Relation between some soil properties and fractions of sorbed phosphorus}

The amount of applied soluble phospate retained in the fluoride-soluble forms is likely to depend on the content of active aluminium and its compounds in the soil. The total linear correlation coefficients between the sorbed $" \mathrm{Al}-\mathrm{P} \|$ and acid oxalate soluble $\mathrm{Al}$ (Table 5) prove that there is this kind of relation also in the present material, although the correlation is close only in the subsoil samples. The corresponding connection between the sorbed $" \mathrm{Fe}-\mathrm{P}$ " and oxalate soluble $\mathrm{Fe}$

Table 5. Total linear correlation coefficients between sorbed $\wedge \mathrm{Al}-\mathrm{P}$ or $\wedge \mathrm{Fe}-\mathrm{P}$ and contents of oxalate soluble sesquioxides, organic carbon and $\mathrm{pH}$

\begin{tabular}{|c|c|c|c|c|c|c|}
\hline \multirow{2}{*}{\multicolumn{2}{|c|}{ Correlation coefficient }} & \multicolumn{5}{|c|}{ Group of samples } \\
\hline & & Topsoil & Subsoil & $\begin{array}{l}\text { Sand and } \\
\text { fine sand }\end{array}$ & Loam and silt & Clay \\
\hline \multirow[t]{3}{*}{ sorbed $\mathrm{Al}-\mathrm{P}$ and } & Al & $0.57 * * *$ & $0.87 * * *$ & $0.69^{* * *}$ & $0.73^{* * *}$ & $0.51 * * *$ \\
\hline & $\mathrm{pH}$ & $-0.25^{* *}$ & -0.21 & -0.14 & $-0.35^{*}$ & $-0.40^{* * *}$ \\
\hline & C \% & $0.49 * * *$ & 0.23 & 0.14 & $0.38^{*}$ & $0.46^{* * *}$ \\
\hline \multirow[t]{3}{*}{ sorbed ${ }^{*} \mathrm{Fe}-\mathrm{P}$ and } & $\mathrm{Fe}$ & $0.72 * * *$ & $0.33^{*}$ & $0.49 * * *$ & $0.59 * * *$ & $0.66^{* * *}$ \\
\hline & $\mathrm{pH}$ & $-0.46^{* * *}$ & -0.08 & $-0.28^{*}$ & $-0.55^{* * *}$ & $-0.51 * * *$ \\
\hline & C \% & $0.21^{*}$ & 0.07 & 0.19 & 0.13 & 0.09 \\
\hline
\end{tabular}

* Significant at 5 per cent level. ** Significant at 1 per cent level. *** Significant at 0.1 per cent level. 
Table 6. Coefficients of determination, $\mathrm{r}^{2}$, and multiple determination, $\mathrm{R}^{2}$, for the relationship of sorbed Al-P, and, $\mathrm{Fe}-\mathrm{P}$, with other soil properties

\begin{tabular}{|c|c|c|c|c|c|}
\hline & \multicolumn{5}{|c|}{ Group of soil Samples } \\
\hline & Topsoil & Subsoil & $\begin{array}{l}\text { Sand and } \\
\text { fine sand }\end{array}$ & $\begin{array}{l}\text { Loam and } \\
\text { silt }\end{array}$ & Clay \\
\hline $\mathrm{r}^{2} \quad \mathrm{Al}-\mathrm{P}$ Al & 0.33 & 0.76 & 0.48 & 0.53 & 0.26 \\
\hline $\mathrm{R}^{2} \mathrm{Al}-\mathrm{P} . \mathrm{Al} \mathrm{pH}$ & 0.34 & 0.77 & 0.49 & 0.56 & 0.29 \\
\hline $\mathrm{R}^{2}$ Al-P. Al pH C & 0.38 & 0.77 & 0.50 & 0.56 & 0.30 \\
\hline $\mathrm{r}^{2} \quad \mathrm{Fe}-\mathrm{P} \mathrm{Fe}$ & 0.51 & 0.11 & 0.24 & 0.35 & 0.43 \\
\hline $\mathrm{R}^{2}$ Fe-P. Fe pH & 0.61 & 0.12 & 0.30 & 0.51 & 0.47 \\
\hline $\mathrm{R}^{2} \mathrm{Fe}-\mathrm{P}$. Fe pH C & 0.61 & 0.12 & 0.50 & 0.56 & 0.61 \\
\hline
\end{tabular}

is very weak in the subsoils, but fairly distinct in the topsoils. In some groups a weak negative correlation exists between the amounts of sorbed phosphorus and soil $\mathrm{pH}$, but the low correlation coefficients between the sorbed phosphorus and soil organic carbon content are positive.

According to the coefficients of determination and multiple determination, the part of the variation in the amounts of sorbed $" \mathrm{Al}-\mathrm{P} n$ or $" \mathrm{Fe}-\mathrm{P} n$ which may be explained on the basis of the variation in these three soil properties differs markedly in the various soil groups. The figures in Table 6 show that while in the subsoil samples as much as 77 per cent of the variation in the amount of sorbed $" \mathrm{Al}-\mathrm{P} n$ may be explained by the content of $\mathrm{Al}$ and $\mathrm{pH}$, taking into account also the content of organic $\mathrm{C}$ determines only 38 per cent of it in the topsoil samples, and in the clay soils this part remains as low as 30 per cent. It seems that the variations in $\mathrm{pH}$ and the content of organic $\mathrm{C}$ are of more importance in explaining the variation in the sorbed $" \mathrm{Fe}-\mathrm{P} \|$ than in the sorbed $" \mathrm{Al}-\mathrm{P}$. Yet, the highest part of the variation in the former which is explainable by the variation in $\mathrm{Fe}, \mathrm{pH}$ and organic $\mathrm{C}$ is only 61 per cent, and in the subsoils this part is almost negligible.

To find some of the factors on which the distribution of applied phosphate in the aluminium bound and iron bound fractions may depend, the relation between the ratio of sorbed $" \mathrm{Al}-\mathrm{P} n$ to sorbed $" \mathrm{Fe}-\mathrm{P} n$ and the ratio of acid oxalate soluble $\mathrm{Al}$ to $\mathrm{Fe}, \mathrm{pH}$, the content of organic carbon, the indicator of phosphate sorption capacity, $\mathrm{k}$, and the degree of saturation, $\mathrm{y}_{\mathrm{o}} / \mathrm{k}$, was studied. The total linear correlation coefficients computed indicated that there is a positive correlation between the ratios $" \mathrm{Al}-\mathrm{P} n / n \mathrm{Fe}-\mathrm{P} "$ and $\mathrm{Al} / \mathrm{Fe}$, the coefficients of correlation ranging from $0.43^{* *}$ in the group of loam and silt soils to $0.66^{* * *}$ in the group of topsoil samples. No total linear correlation could be found between the ratio $n \mathrm{Al}-\mathrm{P} \| / \mathrm{Fe}-\mathrm{P} n$ and the other characteristics studied. Further statistical treatment showed, however, that in some of the soil groups, the phosphate sorption capacity is of certain importance in determining the distribution of the sorbed $\mathrm{P}$ between the fluoride-soluble and alkali-soluble fractions. The coefficients of determination and multiple determination in Table 7 indicate that in some soil groups taking in account the value $\mathrm{k}$, in 
Table 7. Coefficients of determination, $\mathrm{r}^{2}$, and multiple determination, $\mathrm{R}^{2}$, for the relation between the rations of sorbed $\wedge \mathrm{Al}-\mathrm{P} /, \mathrm{Fe}-\mathrm{P}$ and total $\wedge \mathrm{Al}-\mathrm{P} / \bullet \mathrm{Fe}-\mathrm{P}$ with other soil properties

\begin{tabular}{|c|c|c|c|c|c|}
\hline & \multicolumn{5}{|c|}{ Group of soil samples } \\
\hline & Topsoil & Subsoil & $\begin{array}{l}\text { Sand and } \\
\text { fine sand }\end{array}$ & $\begin{array}{l}\text { Loam and } \\
\text { silt }\end{array}$ & Clay \\
\hline \multicolumn{6}{|c|}{$1=$ sorbed $A l-\mathrm{P}_{n} / \mathrm{Fe}_{-} \mathrm{P}$} \\
\hline $\mathrm{r}^{2} \quad 1 \quad \mathrm{Al} / \mathrm{Fe}$ & 0.43 & 0.24 & 0.23 & 0.19 & 0.23 \\
\hline $\mathrm{R}^{2}$ 1. $\mathrm{Al} / \mathrm{Fe} \mathrm{pH}$ & 0.43 & 0.30 & 0.23 & 0.21 & 0.24 \\
\hline $\mathrm{R}^{2}$ 1. $\mathrm{Al} / \mathrm{Fe} \mathrm{pH} \mathrm{k}$ & 0.51 & 0.47 & 0.37 & 0.25 & 0.24 \\
\hline \multicolumn{6}{|c|}{$2=$ total, $\mathrm{Al}-\mathrm{P} \theta / \bullet \mathrm{Fe}-\mathrm{P}$} \\
\hline $\mathrm{r}^{2} 2 \mathrm{Al} / \mathrm{Fe}$ & 0.70 & 0.43 & 0.55 & 0.51 & 0.33 \\
\hline $\mathrm{R}^{2}$ 2. $\mathrm{Al} / \mathrm{Fe} \mathrm{pH}$ & 0.71 & 0.48 & 0.55 & 0.55 & 0.33 \\
\hline $\mathrm{R}^{2}$ 2. $\mathrm{Al} / \mathrm{Fe} \mathrm{pH} \mathrm{k}$ & 0.74 & 0.61 & 0.67 & 0.58 & 0.38 \\
\hline
\end{tabular}

addition to the ratio of $\mathrm{Al} / \mathrm{Fe}$ and $\mathrm{pH}$, may increase the part of the variation in the ratio of $n \mathrm{Al}-\mathrm{P}\|/ n \mathrm{Fe}-\mathrm{P}\|$ which can be explained. Yet, not more than 51 per cent of the variation is explained in the group of topsoils, and 47 per cent in the group of subsoils, and the percentages for the other groups are even lower.

It could be supposed that the ratio between the oxalate soluble aluminium and iron would be more closely correlated with the ratio of the total amounts of aluminium and iron bound phosphorus in the samples treated with phosphate than with the ratio of the sorbed amounts. This is actually the case: the total linear correlation coefficients between these former ratios ranges from $0.58 * * *$ in the clay soil samples to $0.84^{* * *}$ in the group of the topsoil samples.

Thus in the latter group 70 per cent of the variation in the ratio of total "Al-P» to total $" \mathrm{Fe}-\mathrm{P} n$ may be explained by the variation in the ratio of $\mathrm{Al} / \mathrm{Fe}$, and this part is increased to 74 per cent, if also the variation in the soil $\mathrm{pH}$ and the indicator of the sorption capacity are taken into account (Table 7). In the other groups this part is somewhat lower, but yet markedly higher than the corresponding percentages for the explanation of the variation of the ratio of the sorbed $" \mathrm{Al}-\mathrm{P} n / n \mathrm{Fe}-\mathrm{P} n$.

\section{Discussion}

The results of the present paper are in accordance with other works $(2,5,8$, 14, etc.) so far that the largest part of the added soluble phosphate retained by these acid soils is found in the fractions which are supposed to be aluminium bound and iron bound phosphorus. On the average, more than 95 per cent of the phosphate retained occurs in these fractions, about 56 per cent in the fluoride soluble forms and about 40 per cent in the alkali-soluble forms.

It may be asked, however, whether this distribution will really correspond to the conditions in the soils at the end of the phosphate treatment, or did any essential changes occur during the fractionation procedure. The washing with saturated so- 
dium cloride solution may have some effects, too (cf. 13). It is likely that the applied phosphorus is more susceptible to these changes than the native soil phosphorus. On the other hand, the treatment of the soil with the phosphate solution may affect the solubility of the native phosphate.

The accuracy of the fractionation procedure in separating the forms of phosphorus bound by aluminium, iron, and calcium, has been critized (1, 10 etc.) In this connection attention must be paid to the possibility that the fluoride-soluble fraction may contain dicalcium phosphate, known to be formed in soils when soluble phosphate has been applied $(4,5,9)$. Thus, the total net increase in the fluoride-soluble fraction may not be phosphorus bound by aluminium and its compounds. The relatively low net increase in the acid-soluble fraction of one third of these acid samples is likely to be partly caused by the liberation by acid of phosphorus in the treated samples which properly belongs to the resistant reductant soluble fraction.

All this means that certain caution is needed when conclusions are drawn on the basis of the results obtained. There are, however, some observations which appear to be fairly reliable. There seem to be significant differences between the sorption of applied soluble phosphate by the various kinds of soils. In the group of the clay soils, the mean value for the amount of sorbed phosphorus, 57 per cent of the phosphorus added, is significantly higher than the corresponding values, 45 per cent for the sand and fine sand soils, and 44 per cent for the loam and silt soils. This difference is mainly due to a higher retention of phosphorus in the alkalisoluble forms in the clay soils; the average net increase in the fluoride-soluble fractions is of the same order in all of them.

The average ratio between the net increase in the fluoride-soluble fraction and the alkali-soluble fraction is highest in the sand and fine sand soils and lowest in the clay soils, but even in the latter group it is more than 1 . Actually, only in 15 samples, most of them Litorina soils, more applied phosphorus was found in the alkali-soluble than in the fluoride-soluble fraction. The soil acidity appeared to have very little effect on the distribution of added phosphate in these two fractions under the conditions of the present experiments. There was some tendency to a higher accumulation of alkali-soluble than fluoride-soluble phosphate with an increase in the phosphate sorption capacity of the soil. This is in accordance with the observations made by McLEAN and his co-workers $(9,11)$ on their smaller materials.

In the subsoil samples, 76 per cent of the variation in the sorbed fluoridesoluble phosphorus may be explained by the variation in the contents of oxalate soluble aluminium, while in the topsoils the corresponding part is only 33 per cent. This could be connected with the higher grade of phosphate saturation and the higher content of initial phosphorus in this fraction in the topsoils. Yet, the coefficient of determination for the relation between the total amount of fluoridesoluble phosphorus in the treated samples and the oxalate soluble aluminium is only 0.16 in the topsoil samples and 0.74 in the subsoil samples, which means that other explanations are necessary. It seems that more studies are needed also to explain the fact that in the present material, 61 per cent of the variation in the 
net increase in the alkali-soluble forms in the topsoils is determined by the content of oxalate soluble iron and $\mathrm{pH}$, while the corresponding part is only 12 per cent in the subsoils.

One probable explanation for the failure to connect the distribution of the retained phosphorus more closely with the soil properties studied may be found in the fact that at the end of the four days' period of treatment the phosphorus conditions in the soil samples were far from an equilibrium state. It is also likely that the distance from the equilibrium was different in the different samples.

In the present work, the soil samples were treated with an amount of phosphorus which corresponded to $250 \mathrm{mg}$ per kilogram of the soil. Attention is called to the fact that the results may be essentially different, if higher or lower amounts of phosphate are applied.

\section{$S u m m a r y$}

The distribution of soluble phosphate in various fractions of soil phosphorus was studied by treating $1 \mathrm{~g}$-samples of 180 mineral soils with $50 \mathrm{ml}$ of a $\mathrm{KH}_{2} \mathrm{PO}_{4^{-}}$solution containing P $5 \mathrm{mg} / 1$ for 24 hours, and carrying out the fractionation by the method of CHANG and JACKSON after the solution was removed and the moist samples had stood for 3 days at room temperature. The amount of retained phosphorus in the different fractions was computed by taking the difference between the treated and check samples.

In the 70 samples of clay soils, the mean proportion of the retained phosphorus was 57 per cent of the $250 \mathrm{mg} / \mathrm{kg}$ applied, in the 62 samples of the sand and fine sand soils the corresponding part was 45 per cent, and in the 48 samples of loam and silt soils it was 44 per cent. The higher retention in the clay soils was mainly due to a higher retention in the alkali-soluble fraction. The net increase in the fluoride-soluble forms was of the same order in these three soil groups. On the average, more than 95 per cent of the sorbed phosphorus was found in the fluoridesoluble and alkali-soluble fractions. In one third of the samples a low net increase in the acid soluble fraction was detected, but this may be partly due to changes in the solubility of the native phosphorus in the treated samples. Owing to the fairly large variation, the tendency to somewhat higher mean values for the sorption in the subsoils compared with those of the topsoils was not statistically significant.

The ratio between the sorbed amounts of fluoride-soluble and alkali soluble forms was higher in the sand and fine sand soils than in the clay soils. Only in 15 samples, most of them Litorina-soils, the net increase in the alkali-soluble forms was higher than in the fluoride-soluble fraction.

Probably, because an equilibrium in the phosphorus conditions was not yet reached at the end of the treatment, the attempt failed to find any clear connection between the distribution of the sorbed phosphorus and such soil properties as $\mathrm{pH}$, the contents of acid oxalate soluble aluminium and iron, organic carbon, the phosphate sorption capacity and the degree of phosphate saturation. Only in the 
subsoil samples, 76 per cent of the variation in the net increase in the fluoridesoluble fraction could be explained by the variation on the content of oxalatesoluble aluminium, and in the topsoil samples the oxalate-soluble iron and $\mathrm{pH}$ determined 61 per cent of the variation in the net increase in the alkali-soluble phosphorus. The ratio of oxalate-soluble aluminium to iron was more closely correlated with the ratio between the total amounts of fluoride-soluble and alkalisoluble phosphorus than with the ratio between the corresponding sorbed amounts. In the topsoils, it explained 70 per cent of the variation in the former.

The distribution of the retained phosphorus did not depend on the soil $\mathrm{pH}$, its content of organic carbon, or its degree of phosphate saturation but there was some tendency to a higher accumulation of alkali-soluble phosphorus compared with the fluoride-soluble forms with an increase in the phosphate sorption capacity of the soil.

\section{REFERENCES}

(1) Aung Khin \& Leeper, G. W. 1960. Modifications in Chang and Jackson's procedure for fractionating soil phosphorus. Agrochimica IV: 246-245.

(2) Chang, S. C. \& ChU, W. K. 1961. The fate of soluble phosphate applied to soils. J. Soil Sci. 12: 286 -293 .

(3) - - \& JAckson, M. L. 1957. Fractionation of soil phosphorus. Soil Sci 84: 133-144.

(4) KAILA, A. 1961. Fertilizer phosphorus in some Finnish soils. J Sci. Agr. Soc. Finland 33: 131-139.

(5) -1 1963. Fertilizer phosphorus in various fractions of soil phosphorus. Ibid. 35: $36-46$.

(6) - -1963 . Dependence of the phosphate sorption capacity on the aluminium and iron in Finnish soils. Ibid. 35: 165-177.

(7) - - 1964. Fractions of inorganic phosphorus in Finnish mineral soils. Ibid. 36: 1-13.

(8) Laverty, J. C. 1960. Magnitudes and forms of phosphates retained in acid soils. Diss. Abs. 20: 3491 -2. Ref. J. Sci. Food Agric. 11: ii 195.

(9) - - \& McLean, E. O. 1961. Factors affecting yields and uptake of phosphorus by different crops: 3. Soil Sci. 91: 166-171.

(10) MadL, W. 1961. Bindung und Verteilung des Phosphors on Böden der Bayerischen Moränenlandschaft. Veroff. Inst. Bodenk. d. Forstl. Forsch. Anst. München, 175 p.

(11) Volk, V. V. \& McLean, E. O. 1963. The fate of applied phosphorus in four Ohio soils. Soil Sci. Soc. Amer. Proc. 27: 53-58.

(12) WEIR, C. C. \& SoPER, R. J. 1962. Adsorption and exchange studies of phosphorus in some Manitoba soils. Canad. J. Soil Sci. 42: $31-42$.

(13) WILD, A. 1950. The effect of neutral salts on the retention of phosphate by clay at various $\mathrm{pH}$ values. Trans. Int. Cong. Soil Sci. Amsterdam 1950 I: 146-148.

(14) Yuan, T. L. \& Robertson, W. K.\& Neller, J. R. 1960. Forms of newly fixed phosphorus in three acid sandy soils. Soil Sci. Soc. Amer. Proc. 24: 447-450. 
SELOSTUS:

\title{
ÄSKETTÄIN LISÄTYN FOSFORIN SITOUTUMISESTA KIVENNÄISMAISSA
}

\author{
ARMi KaIla
}

\section{Maanviljelyskemian laitos, Helsingin yliopisto}

Laboratoriokokeissa käsiteltiin 180 maanäytettä suhteessa $1: 50 \quad \mathrm{KH}_{2} \mathrm{PO}_{4}$-liuoksella, jossa oli $5 \mathrm{mg} / 1 \mathrm{P}$. Tästä määrästä pidättyi vuorokauden kuluessa savimaihin keskimäärin $57 \%$, hiekka- ja hietamaihin $45 \%$ ja hiue- ja hiesumaihin $44 \% .3$ vuorokautta myöhemmin suoritetun fraktioinnin tulosten mukaan keskimäärin yli $95 \%$ pidättyneestä fosforista oli sitoutunut fluoridiin ja emäkseen liukenevaan muotoon. Savimaiden suurempi fosforin pidätys johtui voimakkaammasta sitoutumisesta emäkseen liukenevaan muotoon.

Suhde pidättyneen fluoridiin liukenevan ja emäkseen liukenevan fosforin välillä oli hiekka- ja hietamaissa suurempi kuin savimaissa. Vain 15 näytteessä, jotka olivat enimmäkseen Litorina-maita, pidättyi fosforia enemmän emäkseen kuin fluoridiin liukenevaan muotoon.

Pidättyneen fosforin sijoittuminen eri fraktioihin kytkeytyi jossain määrin maan oksalaattiin liukenevan aluminiumin ja raudan pitoisuuksiin sekä näiden keskinäiseen suhteeseen. pH, orgaanisen hiilen pitoisuus ja maan kyllästysaste fosforin suhteen eivät näyttäneet vaikuttavan fluoridiin ja emäkseen liukenevan fosforin keskinäiseen suhteeseen. Sen sijaan maan fosforinpidätyskapasiteetin kasvaessa näytti emäkseen liukenevaan muotoon pidättyvän fosforin suhteellinen osuus keskimäärin kasvavan. 